\title{
Frequent detection of Merkel cell polyomavirus DNA in sera of HIV-1-positive patients
}

Hitomi Fukumoto ${ }^{1,2}$, Yuko Sato ${ }^{1}$, Hideki Hasegawa ${ }^{1}$ and Harutaka Katano ${ }^{1 *}$

\begin{abstract}
Background: Merkel cell polyomavirus (MCPyV), human polyomavirus-6 (HPyV6), and human polyomavirus-7 (HPyV7) were identified as viruses shed from the skin. Serological analysis revealed that these viruses are common among the general population. However, there is little information about the presence of MCPYV, HPyV6, and HPyV7 in the sera and tissues of immunocompromised individuals. The aims of this study are to know if immune status affects the presence of MCPyV, HPyV6, and HPyV7 in the serum, and to reveal the presence of these viruses in diseased tissues of unknown etiology.

Methods: Sera from HIV-1-positive and -negative patients were examined by real-time PCR and nested PCR detecting MCPyV, HPyV6 and HPyV7. In addition, diseased tissue samples of unknown etiology were examined.

Results: Nine out of 23 serum samples (39.1\%) from HIV-1-positive patients who had not received anti-retroviral therapy were positive for MCPyV, which is significantly higher than HIV-1-negative patients $(6 / 110,5.5 \%, P<0.01$, Chi-square test). MCPyV DNA was detected in tissue samples of Merkel cell carcinoma (22/30 [73\%]), encephalitis (4/19 [21\%]), pneumonia (3/17 [18\%]), and myocarditis (8/14 [57\%]). With the exception of Merkel cell carcinoma samples, MCPyV-positive tissues showed low copy numbers of MCPyV DNA by real-time PCR and no expression of the MCPyV large T antigen by immunohistochemistry. HPyV6 and HPyV7 were rarely detected in serum and tissue samples.
\end{abstract}

Conclusions: These results suggest that MCPyV viremia is associated with host immunity, and that circulation of HPyV6 and HPyV7 in the serum is rare.

Keywords: Merkel cell polyomavirus, Human polyomavirus, HPyV6, HPyV7, Real-time PCR, HIV-1

\section{Background}

Polyomavirus is a genus of non-enveloped viruses with a circular double-stranded DNA genome of approximately $5 \mathrm{~kb}$. To date, 9 polyomaviruses have been discovered in humans: BK virus [1], JC virus [2], KI virus [3], WU virus [4], Merkel cell polyomavirus (MCPyV) [5], human polyomavirus-6 and 7 (HPyV6 and HPyV7) [6], trichodysplasia spinulosa-associated polyomavirus [7], and HPyV9 [8].

$\mathrm{MCPyV}$ is the fifth human polyomavirus. It was identified in a patient with Merkel cell carcinoma (MCC) by using digital transcriptome subtraction [5]. MCC is a rare but aggressive neuroendocrine skin tumor, with approximately $80 \%$ of cases positive for MCPyV [9-22].

\footnotetext{
* Correspondence: katano@nih.go.jp

'Department of Pathology, National Institute of Infectious Diseases, Shinjuku, Tokyo 162-8640, Japan

Full list of author information is available at the end of the article
}

Serological tests revealed that the majority of adults are seropositive for MCPyV, with seroprevalence to the MCPyV VP1 capsid protein ranging from $46 \%$ to $88 \%$ in the general population, indicating high $\mathrm{MCPyV}$ prevalence among the general population [6,23-25]. A recent study revealed the serological evidence of the MCPyV primary infection in childhood [26]. MCPyV is detected not only in MCC tissues but also in several tissues including skin, oral cavity, liver, colon, lung, kidney, and saliva of patients without MCC, suggesting MCPyV is widespread in the human body [16,27]. In addition, a very high detection rate (about 90\%) was reported in samples of environmental surfaces in contact with human skin by PCR, suggesting shedding of MCPyV from the skin [28]. However, detail of virus titer in the blood is unknown. It is reported that MCPyV DNA was not detected by PCR in sera from 57 immunocompetent
Ciomed Central

(c) 2013 Fukumoto et al.; licensee BioMed Central Ltd. This is an Open Access article distributed under the terms of the Creative Commons Attribution License (http://creativecommons.org/licenses/by/2.0), which permits unrestricted use, distribution, and reproduction in any medium, provided the original work is properly cited. 
patients [29]. Another PCR study demonstrated that 3 (15\%) of 20 immunosuppressed patients were positive for MCPyV DNA in the serum [30].

In a recent study, HPyV6 and $\mathrm{HPyV} 7$ were isolated from skin swabs of healthy donors by using rolling circle amplification (RCA) [6]. The study suggests that infection by these viruses is common among the general population, showing a seroprevalence of $69 \%$ for HPyV6 and $35 \%$ for $\mathrm{HPyV} 7$ in a cohort of 95 blood donors. However, the presence of HPyV6 and HPyV7 DNA in sera has not been reported. In addition, previous studies have not found evidence for a strong association between HPyV6 or HPyV7 infection and any disease. For example, 1 study detected HPyV6 and HPyV7 DNA in only $14 \%$ and $2 \%$ of skin samples of patients with skin cancer $(n=108)$, respectively [31]. Other studies were unable to detect HPyV6 and HPyV7 in neuroendocrine tumors $(n=50)$ and MCC samples $(n=28)[32,33]$.

MCC occurs more frequently in HIV-1-positive patients than in immunocompetent hosts [34-37]. A study using nested PCR analysis showed that HIV-1-positive men had MCPyV DNA in the skin of forehead more frequently than HIV-1-negative healthy controls [38]. In addition, reactivation of human polyomaviruses such as KI polyomavirus and WU polyomavirus was demonstrated in immunocompromised hosts [39]. However, little information about the presence of MCPyV, HPyV6, and $\mathrm{HPyV7}$ in the sera of immunocompromised individuals is available. Moreover, these viruses have not been examined in samples of patients with diseases of unknown etiology. In the present study, sera from HIV-1 -positive and -negative patients were examined by realtime PCR and nested PCR to know if immune status affects the presence of MCPyV, HPyV6, and HPyV7 in the serum. In addition, diseased tissue samples of unknown etiology were examined.

\section{Results}

\section{Frequent detection of MCPyV in sera of HIV-1-positive} patients

MCPyV was detected in 9 of $23 \mathrm{HIV}-1$-positive sera (39.1\%) and 6 of 110 HIV-1-negative sera (5.5\%) by realtime PCR (Table 1). The positivity of MCPyV among HIVpositive patients was significantly higher than that among HIV-1-negative patients $(\mathrm{P}<0.01$, Chi-square test). In $\mathrm{MCPyV}$-positive sera, there was no significant difference in MCPyV copy number between HIV-1-positive (mean =

Table 1 MCPyV, HPyV6, and HPyV7 detection in serum samples by real-time PCR

\begin{tabular}{lcccc}
\hline Patient & $\mathbf{n}$ & MCPyV & HPyV6 & HPyV7 \\
\hline HIV+ & 23 & $9(39.1 \%)$ & $0(0 \%)$ & $0(0 \%)$ \\
HIV- & 110 & $6(5.5 \%)$ & $2(1.8 \%)$ & $0(0 \%)$ \\
\hline
\end{tabular}

26.5 copies per $\mu \mathrm{L}$ ) and HIV-1-negative patients (mean = 45.1 copies per $\mu \mathrm{L}, \mathrm{P}=0.09$, Mann-Whitney $U$-test) (Figure 1). Six MCPyV-positive sera in HIV-1-negative patients were two from congenital immunodeficiency patients, one from a sudden death patient with unknown etiology, and three from myocarditis patients. Dot blots on CD4 and MCPyV copy revealed that CD4 counts in the HIV-1-positive patients were not correlated with MCPyV copy numbers in the serum $\left(R^{2}=0.034\right.$, Figure 2$)$. HPyV6 ST DNA was also detected by real-time PCR in 0 and 2 cases of HIV-1-positive and HIV-1-negative sera, respectively. The two HPyV6 positive HIV-1-negative sera which were taken from autopsy cases of elder patients with respiratory failure were negative for MCPyV. HPyV7 was not detected in any serum sample by real-time PCR.

\section{MCPyV, HPyV6, and HPyV7 detection in tissue samples}

MCPyV was detected in 22/30 (73\%) tissue samples of MCC, 4/19 (21\%) of encephalitis, 3/17 (18\%) of pneumonia, $8 / 14$ (57\%) of myocarditis, and $0 / 10(0 \%)$ of hepatitis by real-time PCR (Table 2). There was no specific histological difference between $\mathrm{MCPyV}$-positive and negative cases in each group. Eleven MCPyV-positive samples of other group in Table 2 were composed of 6 AIDSassociated Kaposi's sarcoma, 4 AIDS-associated lymphoma, and one AIDS-associated progressive multifocal leukoencephalopathy cases. Among MCPyV-positive tissues, the mean MCPyV copy number was significantly higher in the MCC tissues (3.219 copy per cell) than in the other tissues (0.075 copy per cell, $\mathrm{P}=0.0014$, MannWhitney $U$-test, Figure 3$)$. The MCPyV large $\mathrm{T}$ antigen was detectable by immunohistochemistry only in the MCC samples (Figure 4). One MCPyV-positive MCC tissue was also positive for HPyV6 ST DNA, but HPyV6 and $\mathrm{HPyV} 7$ were not detected in any MCPyV-negative

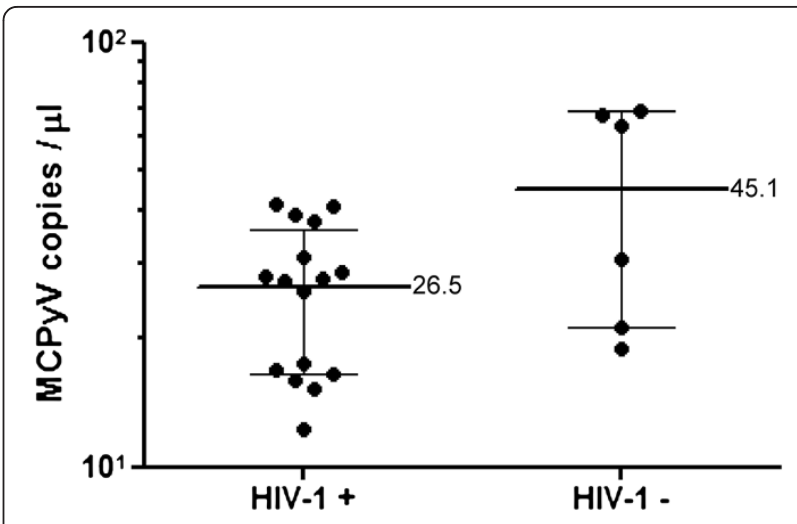

Figure 1 MCPyV copy number in serum samples from HIV-1+ and HIV-1- patients. MCPyV copy number per $\mu \mathrm{L}$ of serum is shown. Horizontal and vertical bars indicate the mean and standard deviation, respectively. The mean MCPyV copy number per $\mu \mathrm{L}$ is shown in the right of each bar. 


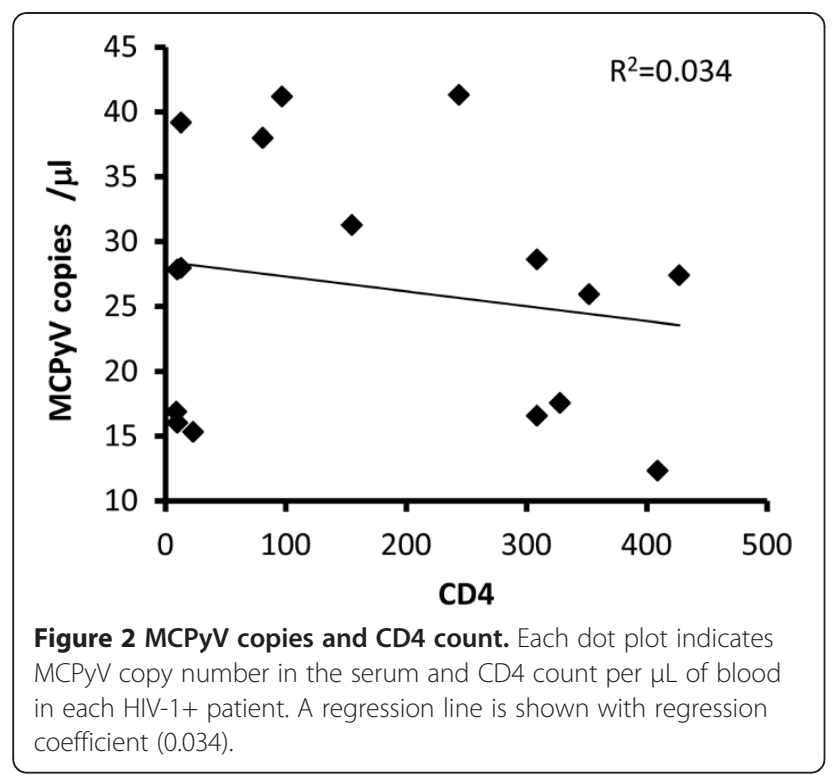

MCC tissues, suggesting no association between MCPyV-negative MCC and HPyV6 or HPyV7 infection. One MCC sample and a tissue sample from a Kaposi's sarcoma patient were positive for HPyV6 ST DNA by real-time PCR (Table 2). HPyV7 was not detected in any tissue sample.

\section{Detection of HPyV6 DNA fragments in nested PCR}

We carried out nested PCR analysis on two serum and two tissue samples which were positive for HPyV6 by real-time PCR detecting HPyV6 ST DNA. The nested PCR were able to amplify their targets from ten genome copies constantly, and did not cross-react with JCV, $\mathrm{BKV}$, and MCPyV genomes (Figure 5A). Nested PCR analysis revealed that HPyV6 VP2/3 DNA were failed to detect in all these cases, whereas a positive control of HPyV6, a DNA sample extracted from a skin biopsy which was confirmed to be HPyV6-positive, was positive for VP2/3 (Figure 5B). HPyV6 LT DNA was negative in the one serum and one tissue samples, and VP1 was positive only in one MCPyV-positive MCC case by nested PCR.

Table 2 MCPyV, HPyV6, and HPyV7 detection in tissue samples by real-time PCR

\begin{tabular}{cccccc}
\hline Disease & Organ & $\mathbf{n}$ & MCPyV & HPyV6 (ST) & HPyV7 (ST, VP1) \\
\hline MCC & skin & 30 & $22(73.3 \%)$ & $1(3.3 \%)$ & $0(0 \%)$ \\
Encephalitis & brain & 19 & $4(21.1 \%)$ & $0(0 \%)$ & $0(0 \%)$ \\
Pneumonia & lung & 17 & $3(17.6 \%)$ & $0(0 \%)$ & $0(0 \%)$ \\
Myocarditis & heart & 14 & $8(57.1 \%)$ & $0(0 \%)$ & $0(0 \%)$ \\
Hepatitis & liver & 10 & $0(0 \%)$ & $0(0 \%)$ & $0(0 \%)$ \\
Other & various & 60 & $11(18.3 \%)$ & $1 *(1.6 \%)$ & $0(0 \%)$
\end{tabular}

* One HPyV6-positive sample in other group is a Kaposi's sarcoma tissue.

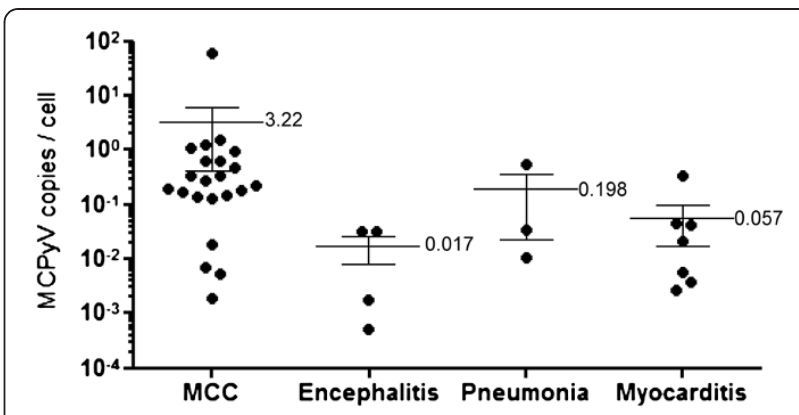

Figure $\mathbf{3}$ MCPyV copies per cell in tissue samples. The mean MCPyV copy number per cell is shown in the right of each bar. Error bars indicate standard error.

\section{Discussion}

In the present study, we detected MCPyV DNA more frequently in the sera of HIV-1-positive patients than in the sera of HIV-1-negative patients. Although detailed characteristics of the HIV-1-positive patients were not available, we confirmed that these patients were not receiving antiretroviral therapy and more than half of

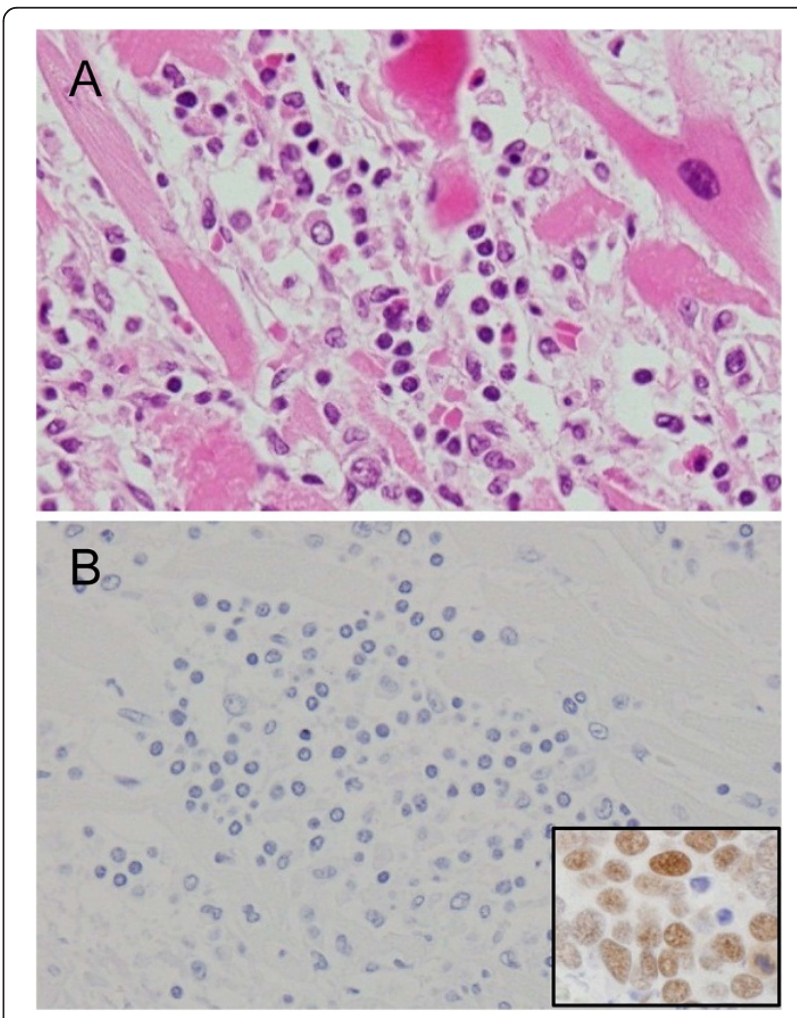

Figure $4 \mathrm{Immunohistochemistry} \mathrm{for} \mathrm{MCPyV} \mathrm{in} \mathrm{tissue} \mathrm{samples.}$ (A) Hematoxylin and eosin staining of a sample of a patient with myocarditis positive for MCPyV by real-time PCR. Remarkable inflammatory cell infiltration is observed in the muscle of the heart. (B) MCPyV large T antigen cannot be detected by immunohistochemistry in the inflammatory cells and myocardial cells. Inset indicates a positive control of Merkel cell carcinoma which had 0.7 copy per cells of MCPyV by real-time PCR. 


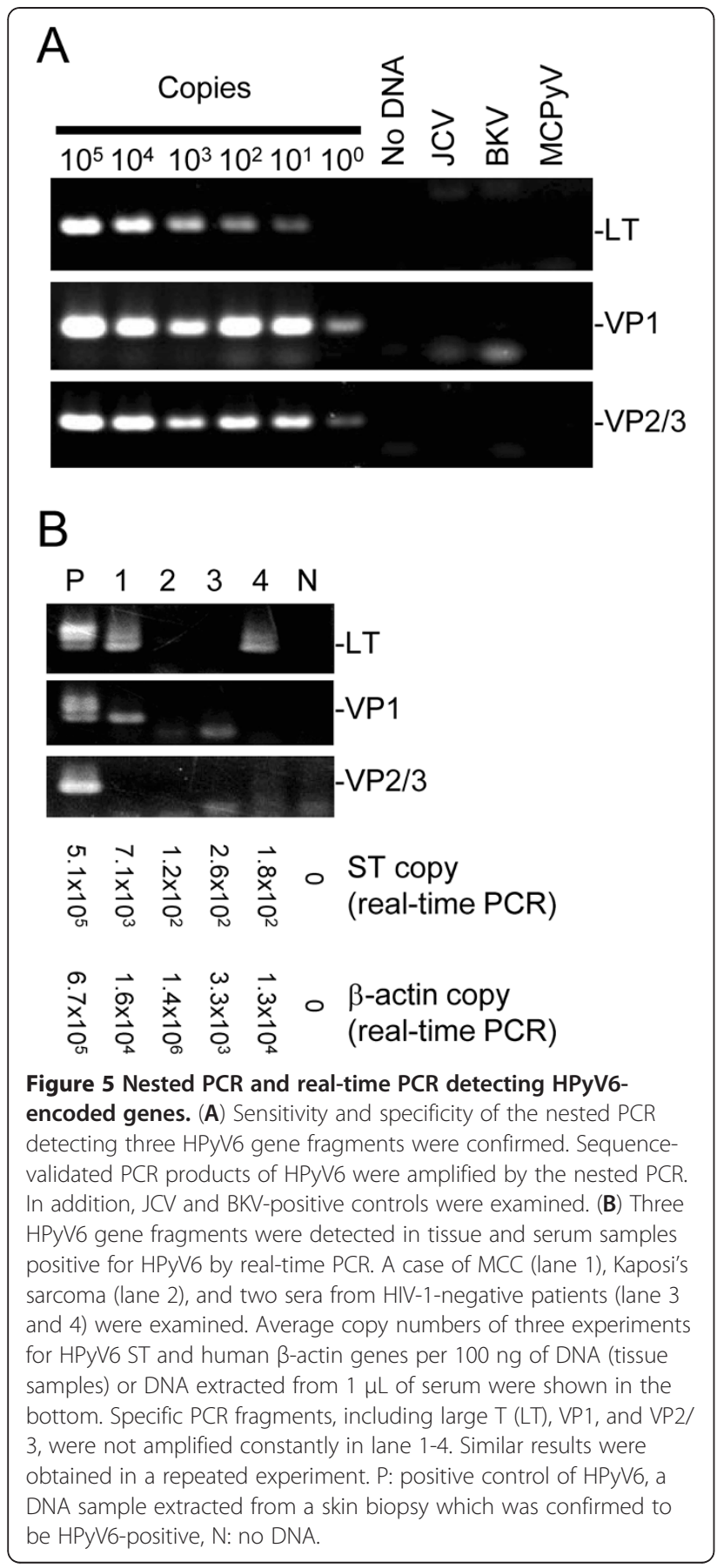

them developed AIDS at the time of blood collection, suggesting that the patients were immunocompromised. Although the correlation between CD4 counts and $\mathrm{MCPyV}$ copies was not shown in the present study (Figure 2) and the detailed immune status was not determined in the HIV-1-negative patients, the significantly different positivity of MCPyV DNA in the serum between HIV-1-positive and negative patients suggests that an individual's immune status is associated with the production of MCPyV which will be a crucial factor in elucidating MCC pathogenesis. It has been reported that profound immune suppression is one of the important risk factors for MCC development and that patients with AIDS have a 13-fold increased risk for MCC compared with the general population [35]. Thus, a high detection rate of $\mathrm{MCPyV}$ in the serum may be associated with the clinical incidence of MCC.

MCPyV, HPyV6, and HPyV7 were identified as viruses shed from the skin [6]. Seroprevalence data from a cohort of U.S. patients indicates that these 3 viruses are common among the general population $[6,40]$. In contrast, our PCR data showed the presence of viral DNA in less than $10 \%$ of serum samples from HIV-1-negative patients. This finding is consistent with the results by previous reports describing frequent detection of $\mathrm{MCPyV}$ in the skin samples [6], but rare detection of MCPyV DNA in blood samples [29]. Considering these reports and our results, it is suggested that viremia is rare among infected individuals who are not immunocompromised. Although the seroprevalence of the viruses in Japan is unknown, low detection rates of the viruses in serum suggest a low titer of circulating virus or low amounts of viral DNA in the blood of infected individuals. A low detection rate of viral DNA in MCPyVseropositive individuals would suggest that the viruses are produced in the skin and released from the epithelium, but do not circulate in the blood. Because HPyV6 and HPyV7 were rarely detected even in HIV-1-positive serum samples, seroprevalence data on these viruses will be required to interpret the results. In addition, HPyV6 was detected in 4 samples including tissue samples in the present study, but only $1 \mathrm{MCC}$ tissue was positive for both VP1 and ST genes. HPyV6 LT DNA was negative in the one serum and one tissue samples by the nested PCR among the 4 samples positive for HPyV6 ST gene by the real-time PCR. Such different reactivities among polyomavirus-encoded genes in each case were observed in the previous reports of $\mathrm{MCPyV}$ in MCC $[20,22]$, suggesting sequence mutation in the target genes or the presence of partial genomes of HPyV6 in the serum.

MCPyV was detected at a high rate in samples of patients with myocarditis (57\%); additionally, $10-20 \%$ of pneumonia and encephalitis samples were positive. Our results in the present study showed low copy numbers of MCPyV in tissues other than MCC. These findings are constant to previous findings that no or low amounts of MCPyV was detected in normal tissues or neoplastic lesions of organs other than the skin [22]. The previous study demonstrated that MCC cases infected with MCPyV at more than 0.05 copy per cell were positive in immunohistochemistry for $\mathrm{MCPyV}$ large $T$ antigen [41]. Although more than 0.05 copy per 
cell of MCPyV were detected in one pneumonia and one myocarditis cases, immunohistochemistry showed no expression of the MCPyV large $\mathrm{T}$ antigen in tissues other than MCC tissues, indicating no direct association of $\mathrm{MCPyV}$ infection with the pathogenesis of these diseases. However, since MCPyV was detected in inflammatory conditions such as myocarditis and pneumonia by real-time PCR in the present study, MCPyV production may be induced by inflammations or inflammatory cytokines. This observation is compatible with a recent finding that inflammatory monocyte is a reservoir for $\mathrm{MCPyV}$ in vivo [42]. Another possibility is that the virus has an inherent affinity for heart or lung cells. Further investigation of the virus receptor will be required to determine its affinity.

\section{Conclusions}

MCPyV DNA was detected more frequently in the sera of HIV-1-positive patients than in the sera of HIV-1 -negative patients. HPyV6 was detected in less than 2\% of serum and tissue samples, whereas HPyV7 was not detected. These results suggest that MCPyV replication is associated with host immunity, and that circulation of HPyV6 and HPyV7 in the serum is rare.

\section{Methods}

\section{Samples}

This study was approved by the institutional review board at the National Institute of Infectious Diseases (Approval No. 273). We used 23 HIV-1-positive and 111 HIV-1-negative sera stored at the National Institute of Infectious Disease. All the HIV-1-positive patients had not received anti-retrovirus therapy at the time of blood collection. Their CD4 counts at the time of blood collection were recorded for analysis. The HIV-1-negative sera were obtained from patients with various diseases including influenza virus infection, myocarditis, encephalitis, hepatitis, malignancies, etc. No MCC patient was included. In addition, formalin-fixed paraffin-embedded (FFPE) or frozen tissue samples from 150 patients with various diseases such as encephalitis, pneumonia, myocarditis, and hepatitis were collected. DNA samples extracted from JCV-positive progressive multifocal leukoencephalopathy and BKVassociated nephropathy were used as JCV and BKVpositive controls, respectively.

\section{DNA extraction}

DNA was extracted from $50 \mu \mathrm{L}$ of serum by using the DNeasy Blood \& Tissue Kit (Qiagen GmbH, Hilden, Germany) according to the manufacturer's protocol. DNA from sera was eluted in a final volume of $50 \mu \mathrm{L}$ of elution buffer. For tissue samples, DNA was extracted from three pieces of $10 \mu \mathrm{m}$-thick FFPE sections and $10 \mathrm{mg}$ of frozen tissue samples with the Qiaamp FFPE DNA extraction kit and the DNeasy Tissue Kit (Qiagen), respectively. DNA from FFPE and frozen tissues were eluted in a final volume of $30 \mu \mathrm{L}$ and $100 \mu \mathrm{L}$ of elution buffer, respectively.

\section{Real-time PCR}

Real-time PCR was performed using a standard TaqMan ${ }^{\circledR}$ PCR kit protocol (Applied Biosystems, Foster City, CA) on a MX3005P (Stratagene, La Jolla, CA). DNA samples were analyzed for the presence of MCPyV [22], HPyV6 VP1, HPyV6 small T (ST), HPyV7 VP1, and HPyV7 ST genes. The amount of human genomic DNA (as measured by the $\beta$-actin gene) in the DNA extracted from each specimen was also determined. Primers and probes for HPyV6 and HPyV7 were designed for the VP1 and ST regions by using Primer Express software (Applied Biosystems) based on the reference sequences of HPyV6

Table 3 Primer list for HPyV6 nested PCR

\begin{tabular}{|c|c|c|c|c|c|}
\hline Gene & Out/ln & $F / R$ & Primer name & $5^{\prime}-3^{\prime}$ & Product Size \\
\hline \multirow[t]{4}{*}{ HPyV6 LT } & Outer & Forward & HPyV6-LTN4088F1 & ggagcaggattgggttttct & $203 \mathrm{bp}$ \\
\hline & & Reverse & HPyV6-LTN4290R1 & aggccacctccacaatatgg & \\
\hline & Innner & Forward & HPyV6-LTN4109F2 & ttcttaggaggagtgcaaga & $149 \mathrm{bp}$ \\
\hline & & Reverse & HPyV6-LTN4257R2 & gaacaatggtgggctgattt & \\
\hline \multirow[t]{4}{*}{ HPyV6 VP1 } & Outer & Forward & HPyV6-VP1-1347 F1 & ggaggagtggaggttatgga & $166 \mathrm{bp}$ \\
\hline & & Reverse & HPyV6-VP1-1512R1 & acagagatgaaccagcatcc & \\
\hline & Innner & Forward & HPyV6-VP1-1369 F2 & cagtgccactttctgaagac & $122 \mathrm{bp}$ \\
\hline & & Reverse & HPyV6-VP1-1490R2 & agtgtcggtaaaggtgtagg & \\
\hline \multirow[t]{4}{*}{ HPyV6 VP2/3 } & Outer & Forward & HPyV6-VP23-741 F1 & cacttcaactgtggttgcca & $187 \mathrm{bp}$ \\
\hline & & Reverse & HPyV6-VP23-927R1 & tccctagaagctgttctctg & \\
\hline & Innner & Forward & HPyV6-VP23-763 F2 & agtttggtcttggggaggcg & $138 \mathrm{bp}$ \\
\hline & & Reverse & HPyV6-VP23-900R2 & tccctgcctgctctatagta & \\
\hline
\end{tabular}


(GenBank accession no. HM011558) and HPyV7 (HM011569). HPyV6-VP1 forward (5'-CCCTGGCTGT TGTTAATTTGC-3') and reverse (5'-CTGAAGGCTT CCCAAACCAA- $3^{\prime}$ ) primers were used with the TaqMan probe $5^{\prime}$-(FAM) TGAAATTCCTGAGGCCCTGTGTGA TGAT (TAMRA)-3'. HPyV6-ST forward (5'-AAGCA CCAGGTGGGTGATGA-3 ${ }^{\prime}$ ) and reverse (5'-CAACGCC TGAATGTTTTAAAGGA-3') primers were used with the TaqMan probe $5^{\prime}$-(FAM) TTGGTCCCTCAGGGTGGC ATTCAA (BHQ1)-3'. HPyV7-VP1 forward (5'-AGAAG GTCCAGGCAATAGTGATG-3') and reverse (5'-CTGG GAAATTTGCAGCATTTACT-3 ${ }^{\prime}$ ) primers were used with the TaqMan probe $5^{\prime}$-(HEX) AGCTAGCCTGCA AGCCCTCAGAAAGC (BHQ1)-3'. HPyV7-ST forward $\left(5^{\prime}\right.$-CCAGCATTTGCCCCATAAAA- $\left.3^{\prime}\right)$ and reverse $\left(5^{\prime}\right.$ AAAGCATAAGAAGAAGGCCAAAGA-3') primers were used with the TaqMan probe $5^{\prime}$-(HEX) AGGCCCCCG GTGGTCTTTAG (BHQ1)-3'. Primers and probes for MCPyV and $\beta$-actin were described previously [22]. PCR amplification was performed in a $20 \mu \mathrm{L}$ reaction volume by using QuantiTect Multiplex PCR Master Mix (Qiagen), with $0.4 \mu \mathrm{M}$ of each primer, $0.2 \mu \mathrm{M}$ of TaqMan probe, and $1 \mu \mathrm{L}$ of isolated DNA. PCR was carried out at $50^{\circ} \mathrm{C}$ for $2 \mathrm{~min}, 95^{\circ} \mathrm{C}$ for $15 \mathrm{~min}$, and 40 cycles of $94^{\circ} \mathrm{C}$ for $1 \mathrm{~min}$ and $60^{\circ} \mathrm{C}$ for $1 \mathrm{~min}$. Quantitative results were obtained by generating standard curves for sequencevalidated PCR products or plasmids containing HPyV6VP1, HPyV6-ST, HPyV7-VP1, HPyV7-ST, MCPyV-LT, or the cellular target ( $\beta$-actin gene). Virus copy number per cell was calculated as previously described, by dividing the virus copy number by half of the $\beta$-actin copy number, because each cell contains 2 alleles of $\beta$-actin [43]. These real-time PCR amplified at least 10 copies of target gene constantly, and did not cross-react with JCV and BKV in JCV or BKV-positive control samples (data not shown). In addition, HPyV6 and HPyV7 real-time PCR did not amplify any fragment from a plasmid containing a full genome of MCPyV (data not shown).

\section{Nested PCR}

Nested PCR was performed to detect HPyV6 LT, VP1, and VP2/3 gene. Sequences of outer and inner primers are listed in Table 3. The first round of amplification was performed with $100 \mathrm{ng}$ of extracted DNA and high fidelity Taq DNA polymerase (Roche Diagnostics, Boehringer Mannheim, Germany) in a final volume of $25 \mu \mathrm{L}$. After an initial DNA denaturation for $2 \mathrm{~min}$ at $94^{\circ} \mathrm{C}$, samples were amplified by 35 cycles of $94^{\circ} \mathrm{C}$ for $30 \mathrm{sec}, 55^{\circ} \mathrm{C}$ for $30 \mathrm{sec}$ and $72^{\circ} \mathrm{C}$ for $30 \mathrm{sec}$, followed by a final elongation phase of $7 \mathrm{~min}$ at $72^{\circ} \mathrm{C}$. The second round was performed with $1 \mu \mathrm{L}$ of first round PCR product in a final volume of $25 \mu \mathrm{L}$ under the following parameters: $94^{\circ} \mathrm{C}$ for $30 \mathrm{sec}, 55^{\circ} \mathrm{C}$ for $30 \mathrm{sec}, 72^{\circ} \mathrm{C}$ for $30 \mathrm{sec}$ for 25 cycles, followed by a final elongation phase of $7 \mathrm{~min}$ at $72^{\circ} \mathrm{C}$. Five $\mu \mathrm{L}$ of amplification products were loaded onto agarose gels, electrophoresed, stained with bromide and visualized under UV light.

\section{Immunohistochemistry}

Immunohistochemistry was performed on FFPE samples with the rabbit anti-MCPyV-LT polyclonal antibody as the primary antibody, as described previously [41].

\section{Statistical analysis}

Data were analyzed using a Chi-square test or MannWhitney $U$-test on SPSS software (IBM, Armonk, NY).

\section{Competing interests}

The authors declare that they have no competing interests.

\section{Authors' contributions}

HK designed the study and performed statistical analysis. HF and HK performed PCR. YS, HK and HH performed pathological analysis. $\mathrm{HK}$ and $\mathrm{FH}$ drafted the manuscript. All authors read and reviewed the final manuscript.

\section{Acknowledgements}

This work was supported by Health and Labor Sciences Research Grants [No. H22-AIDS-Ippan-002, H23-AIDS-Ippan-002, H24-AIDS-Ippan-003] from the Ministry of Health, Labor and Welfare; Grants-in-Aid for Scientific Research from the Ministry of Education, Culture, Sports, Science and Technology of Japan [No. 21590520, 22390243 and 24659212].

\section{Author details}

'Department of Pathology, National Institute of Infectious Diseases, Shinjuku, Tokyo 162-8640, Japan. ${ }^{2} J a p a n$ Ground Self Defense Force, Signal School, Yokosuka, Kanagawa 239-0828, Japan.

Received: 12 November 2012 Accepted: 6 March 2013

Published: 13 March 2013

\section{References}

1. Gardner SD, Field AM, Coleman DV, Hulme B: New human papovavirus (B.K.) isolated from urine after renal transplantation. Lancet 1971, 1:1253-1257.

2. Padgett BL, Walker DL, ZuRhein GM, Eckroade RJ, Dessel BH: Cultivation of papova-like virus from human brain with progressive multifocal leucoencephalopathy. Lancet 1971, 1:1257-1260.

3. Allander T, Andreasson K, Gupta S, Bjerkner A, Bogdanovic G, Persson MA, Dalianis T, Ramqvist T, Andersson B: Identification of a third human polyomavirus. J Virol 2007, 81:4130-4136.

4. Gaynor AM, Nissen MD, Whiley DM, Mackay IM, Lambert SB, Wu G, Brennan DC, Storch GA, Sloots TP, Wang D: Identification of a novel polyomavirus from patients with acute respiratory tract infections. PLoS Pathog 2007, 3:e64

5. Feng $\mathrm{H}$, Shuda $\mathrm{M}$, Chang $\mathrm{Y}$, Moore PS: Clonal integration of a polyomavirus in human Merkel cell carcinoma. Science 2008, 319:1096-1100.

6. Schowalter RM, Pastrana DV, Pumphrey KA, Moyer AL, Buck CB: Merkel cell polyomavirus and two previously unknown polyomaviruses are chronically shed from human skin. Cell Host Microbe 2010, 7:509-515.

7. van der Meijden E, Janssens RW, Lauber C, Bouwes Bavinck JN, Gorbalenya $A E$, Feltkamp MC: Discovery of a new human polyomavirus associated with trichodysplasia spinulosa in an immunocompromized patient. PLOS Pathog 2010, 6:e1001024

8. Scuda N, Hofmann J, Calvignac-Spencer S, Ruprecht K, Liman P, Kuhn J, Hengel $H$, Ehlers B: A novel human polyomavirus closely related to the african green monkey-derived lymphotropic polyomavirus. J Virol 2011, 85:4586-4590

9. Kassem A, Schopflin A, Diaz C, Weyers W, Stickeler E, Werner M, Zur Hausen $A$ : Frequent detection of Merkel cell polyomavirus in human Merkel cell carcinomas and identification of a unique deletion in the VP1 gene. Cancer Res 2008, 68:5009-5013. 
10. Becker JC, Houben R, Ugurel S, Trefzer U, Pfohler C, Schrama D: MC polyomavirus is frequently present in Merkel cell carcinoma of European patients. J Invest Dermatol 2009, 129:248-250.

11. Busam KJ, Jungbluth AA, Rekthman N, Coit D, Pulitzer M, Bini J, Arora R, Hanson NC, Tassello JA, Frosina D, et al: Merkel cell polyomavirus expression in merkel cell carcinomas and its absence in combined tumors and pulmonary neuroendocrine carcinomas. Am J Surg Pathol 2009, 33:1378-1385.

12. Duncavage EJ, Zehnbauer BA, Pfeifer JD: Prevalence of Merkel cell polyomavirus in Merkel cell carcinoma. Mod Pathol 2009, 22:516-521.

13. Nakajima H, Takaishi M, Yamamoto M, Kamijima R, Kodama H, Tarutani M, Sano S: Screening of the specific polyoma virus as diagnostic and prognostic tools for Merkel cell carcinoma. J Dermatol Sci 2009, 56:211-213

14. Sihto $H$, Kukko H, Koljonen V, Sankila R, Bohling $T$, Joensuu H: Clinical factors associated with Merkel cell polyomavirus infection in Merkel cell carcinoma. J Natl Cancer Inst 2009, 101:938-945.

15. Varga E, Kiss M, Szabo K, Kemeny L: Detection of Merkel cell polyomavirus DNA in Merkel cell carcinomas. Br J Dermatol 2009, 161:930-932.

16. Wieland U, Mauch C, Kreuter A, Krieg T, Pfister H: Merkel cell polyomavirus DNA in persons without merkel cell carcinoma. Emerg Infect Dis 2009, 15:1496-1498

17. Andres C, Belloni B, Puchta U, Sander CA, Flaig MJ: Prevalence of MCPyV in Merkel cell carcinoma and non-MCC tumors. J Cutan Pathol 2010, 37:28-34.

18. Foulongne V, Dereure O, Kluger N, Moles JP, Guillot B, Segondy M: Merkel cell polyomavirus DNA detection in lesional and nonlesional skin from patients with Merkel cell carcinoma or other skin diseases. $\mathrm{Br} J$ Dermatol 2010, 162:59-63.

19. Mangana J, Dziunycz P, Kerl K, Dummer R, Cozzio A: Prevalence of Merkel cell polyomavirus among Swiss Merkel cell carcinoma patients. Dermatology 2010, 221:184-188.

20. Ota S, Ishikawa S, Takazawa Y, Goto A, Fujii T, Ohashi K, Fukayama M: Quantitative analysis of viral load per haploid genome revealed the different biological features of merkel cell polyomavirus infection in skin tumor. PLoS One 2012, 7:e39954.

21. Kuwamoto S, Higaki H, Kanai K, Iwasaki T, Sano H, Nagata K, Kato K, Kato M, Murakami I, Horie Y, et al: Association of Merkel cell polyomavirus infection with morphologic differences in Merkel cell carcinoma. Hum Pathol 2011, 42:632-640.

22. Katano H, Ito H, Suzuki Y, Nakamura T, Sato Y, Tsuji T, Matsuo K, Nakagawa $H$, Sata T: Detection of Merkel cell polyomavirus in Merkel cell carcinoma and Kaposi's sarcoma. J Med Virol 2009, 81:1951-1958.

23. Kean JM, Rao S, Wang M, Garcea RL: Seroepidemiology of human polyomaviruses. PLoS Pathog 2009, 5:e1000363.

24. Pastrana DV, Tolstov YL, Becker JC, Moore PS, Chang Y, Buck CB: Quantitation of human seroresponsiveness to Merkel cell polyomavirus. PLoS Pathog 2009, 5:e1000578.

25. Viscidi RP, Rollison DE, Sondak VK, Silver B, Messina JL, Giuliano AR, Fulp W, Ajidahun A, Rivanera D: Age-specific seroprevalence of Merkel cell polyomavirus, BK virus, and JC virus. Clin Vaccine Immunol 2011, 18:1737-1743

26. Chen T, Hedman L, Mattila PS, Jartti T, Ruuskanen O, Soderlund-Venermo M, Hedman K: Serological evidence of Merkel cell polyomavirus primary infections in childhood. J Clin Virol 2011, 50:125-129.

27. Loyo M, Guerrero-Preston R, Brait M, Hoque MO, Chuang A, Kim MS, Sharma R, Liegeois NJ, Koch WM, Califano JA, et al: Quantitative detection of Merkel cell virus in human tissues and possible mode of transmission. Int J Cancer 2010, 126:2991-2996.

28. Foulongne V, Courgnaud V, Champeau W, Segondy M: Detection of Merkel cell polyomavirus on environmental surfaces. J Med Virol 2011, 83:1435-1439.

29. Dworkin AM, Tseng SY, Allain DC, Iwenofu OH, Peters SB, Toland AE: Merkel cell polyomavirus in cutaneous squamous cell carcinoma of immunocompetent individuals. J Invest Dermatol 2009, 129:2868-2874.

30. Husseiny Ml, Anastasi B, Singer J, Lacey SF: A comparative study of Merke cell, BK and JC polyomavirus infections in renal transplant recipients and healthy subjects. J Clin Virol 2010, 49:137-140.

31. Schrama D, Buck CB, Houben R, Becker JC: No evidence for association of HPyV6 or HPyV7 with different skin cancers. J Invest Dermatol 2011. advance online publication, September 8.
32. Schmitt M, Hofler D, Koleganova N, Pawlita M: Human polyomaviruses and other human viruses in neuroendocrine tumors. Cancer Epidemiol Biomarkers Prev 2011, 20:1558-1561.

33. Duncavage EJ, Pfeifer JD: Human polyomaviruses 6 and 7 are not detectable in Merkel cell polyomavirus-negative Merkel cell carcinoma. J Cutan Pathol 2011, 38:790-796.

34. Becker JC, Kauczok CS, Ugurel S, Eib S, Brocker EB, Houben R: Merkel cell carcinoma: molecular pathogenesis, clinical features and therapy. J Dtsch Dermatol Ges 2008, 6:709-719.

35. Engels EA, Frisch M, Goedert JJ, Biggar RJ, Miller RW: Merkel cell carcinoma and HIV infection. Lancet 2002, 359:497-498.

36. Pulitzer MP, Amin BD, Busam KJ: Merkel cell carcinoma: review. Adv Anat Pathol 2009, 16:135-144.

37. Izikson L, Nornhold E, lyer JG, Nghiem P, Zeitouni NC: Merkel cell carcinoma associated with HIV: review of 14 patients. AIDS 2011, 25:119-121.

38. Wieland U, Silling S, Scola N, Potthoff A, Gambichler T, Brockmeyer NH, Pfister H, Kreuter A: Merkel cell polyomavirus infection in HIV-positive men. Arch Dermatol 2011, 147:401-406.

39. Sharp CP, Norja P, Anthony I, Bell JE, Simmonds P: Reactivation and mutation of newly discovered $\mathrm{WU}, \mathrm{KI}$, and Merkel cell carcinoma polyomaviruses in immunosuppressed individuals. J Infect Dis 2009, 199:398-404.

40. Tolstov $Y L$, Pastrana DV, Feng $H$, Becker JC, Jenkins FJ, Moschos S, Chang $Y$ Buck CB, Moore PS: Human Merkel cell polyomavirus infection II. MCV is a common human infection that can be detected by conformational capsid epitope immunoassays. Int J Cancer 2009, 125:1250-1256.

41. Nakamura T, Sato Y, Watanabe D, Ito H, Shimonohara N, Tsuji T, Nakajima N, Suzuki Y, Matsuo K, Nakagawa H, et al: Nuclear localization of Merkel cell polyomavirus large T antigen in Merkel cell carcinoma. Virology 2010, 398:273-279.

42. Mertz KD, Junt T, Schmid M, Pfaltz M, Kempf W: Inflammatory monocytes are a reservoir for Merkel cell polyomavirus. J Invest Dermatol 2010, 130:1146-1151.

43. Asahi-Ozaki Y, Sato Y, Kanno T, Sata T, Katano H: Quantitative analysis of Kaposi sarcoma-associated herpesvirus (KSHV) in KSHV-associated diseases. J Infect Dis 2006, 193:773-782

doi:10.1186/1743-422X-10-84

Cite this article as: Fukumoto et al:: Frequent detection of Merkel cell polyomavirus DNA in sera of HIV-1-positive patients. Virology Journal 2013 10:84

\section{Submit your next manuscript to BioMed Central and take full advantage of:}

- Convenient online submission

- Thorough peer review

- No space constraints or color figure charges

- Immediate publication on acceptance

- Inclusion in PubMed, CAS, Scopus and Google Scholar

- Research which is freely available for redistribution 